\author{
Z.N. Borbasova ${ }^{1}{ }{ }^{*}$, R.E. Nessipbayev ${ }^{2}$, S.N. Ulakov ${ }^{3}$, N.S. Ulakov ${ }^{4}$ \\ ${ }^{1,2,3,4}$ Karaganda Economic University of Kazpotrebsoyuz, Kazakhstan \\ 'borbasova@mail.ru, 2sani_zizu@mail.ru, ${ }^{3}$, s_ulakov@mail.ru \\ ${ }^{1}$ https://orcid.org/0000-0003-2314-7438, ${ }^{2}$ https://orcid.org/0000-0002-6792-7244 \\ ${ }^{3}$ https://orcid.org/0000-0002-6867-2407 ${ }^{4}$ https://orcid.org/0000-0002-6135-9186 \\ ${ }^{1}$ Scopus Author ID: 57148334500, ${ }^{3}$ Scopus Author ID: 57148290800, ${ }^{4}$ Scopus Author ID: 57189091955

\section{Improvement of regional development using current and strategic territorial management mechanisms}

\begin{abstract}
Object: The successful development of the regions requires certainty and the presence of consolidating ideas about the future. These are important needs of business and society, which are satisfied through the mechanism of territorial socio-economic planning. This article discusses the concept of strategic management, describes the differences between strategic and current management on the example of management of sectors of the social block. The essence of the management of the territorial economy of the region, as well as issues of the implementation of life support and social services of the population, improvement of the territorial economy as a whole was investigated.

Methods: The following methods were used during the research: empirical, analytical, synthetic and comparative logical ones.

Findings: Therefore, the main form of territorial management is the combination of current and strategic management within the governing body. The implementation of this approach requires a very careful attitude to the construction of the internal structure of the management body, taking into account the peculiarities of the organization of different types of management. Let's try to give a more detailed description of the main approaches to building management structures focused on combining current and strategic management.

Conclusions: When forming a strategic planning mechanism, one should proceed from the need to respect the interests of all participants in the development of the territory: government, business, and the public. But the driving force is always the government: it not only realizes its interest, but also creates conditions for the effective functioning of enterprises, improving the investment climate of the territory, provides equal competitive opportunities for all partners in the region. A well-developed strategic plan is the basis for implementing more detailed plans for each year.
\end{abstract}

Keywords: region, territory economy, strategy, mechanism, information, territorial socio-economic planning.

\title{
Introduction
}

When considering the main fundamental difference between strategic and ongoing management, it can be concluded that it is for management purposes. Different types of management differ, first of all, in the achievement of what result they are aimed at. In our case, when it comes to managing the territorial economy of the region, the goals of the authority are to maintain the existing systems through which the needs of residents are realized (primarily life support and social services for the population), as well as the development of the territorial economy as a whole, and its acquisition of new qualitative characteristics of a higher level.

The current management acts as a system of managerial influences aimed at maintaining and functioning systems that ensure the existence and development of the territory. Unlike the current one, strategic management is aimed at creating new qualitative characteristics of a higher level for the entire territorial economy of the region. But these differences in goals do not mean a rigid separation between the non-strategic (current) and strategic management of the region's territorial economy. Moreover, such a contrast is extremely harmful. Since, without setting priorities for the development of the territorial economy as a whole, it is impossible to prioritize the current management of sectors of the territorial economy. On the other hand, the current management state is the most important resource of strategic management, and improving the quality

\footnotetext{
"Corresponding author.

E-mail address: borbasova@mail.ru
} 
of current management is one of the strategic tasks. But in the absence of a clearly expressed strategy for the development of the territory as a whole, it is impossible to see and assess the role and place of each branch of the territorial economy for the future.

Nevertheless, despite the close linkage between current and strategic governance, we need to address them separately within our task, as methods and tools will be very different. And most importantly, when these two types of management are mixed, performance decreases, since the motivations of the management structures in the implementation of different types of management differ significantly.

\section{Methods}

Let's consider these differences using the example of social block industry management. In carrying out the current management, we will first of all be interested in ensuring the activities of a network of educational institutions, health care, etc. For example, the state of the region's education system, its ability to adapt rapidly to the interests of economic clusters (in the training of specialized labor, production and reproduction of innovations and know-how) operating in the territory, is one of the most important conditions for the territory's competitiveness (Gruzdev, 2008).To solve this problem, we need to develop funding standards and solve the main issues of maintaining institutions, lay down the main parameters of the network by agreeing on cost estimates and forming the conditions for a municipal order. To do this, the current planning of the development of industries is carried out, the corresponding regulatory framework is formed. Industry departments administer and monitor compliance with the basic parameters laid down in the budget and annual plan.

In the case of strategic management, at every given moment it is fixed what the organization (in this case, the state, approx. Author) must do at present in order to achieve the desired goals in the future, based on the fact that the environment and living conditions of the organization will change, that is, in strategic management, as if there is a view from the future to the present (Merenkova, 2011). The actions of the organization are defined and carried out at present, providing it with a certain future, and not a plan or description of what the organization will have to do in the future.

First, unlike non-strategic management, it is characteristic that not only the desired future state of the organization is recorded, but also this is the most important task of strategic management, the ability to respond to changes in the environment that allow achieving the desired goals in the future is developed.

Second, in non-strategic management, the formulation of a programme of action begins with an analysis of the organization's internal capabilities and resources. With this approach, all an organization can determine based on an analysis of its internal capabilities is how much product it can produce and what costs it can incur. But the volume of production, and the amount of costs does not give an answer to the question of how much the created product will be accepted by the market, how much will be bought and at what price, the market will determine.

Completely different management methods will be implemented in strategic management. The first task will be to adjust the main parameters of the network based on strategic priorities (opening new specialties in educational institutions that ensure the development and activities of business entities, encouraging the opening of centers of innovation and know-how at educational institutions, organizing more creative competitions, work with associations of economic details subjects to organize their interaction with social sectors, etc.). In strategic management, the social sphere is considered not only as a system for meeting the basic needs of the inhabitants of the territory, but also as a resource (specialized education and health care, a system for the flow of knowledge, innovation, know-how, etc.).

The scope of direct administration, rationing and municipal order is sharply limited compared to current management. This is due primarily to restrictions on the spending of budget funds and the use of state and municipal property. In this area, we can only strengthen certain positions within the framework of permitted financing items and prioritization in the use of public property. In other words, to form conditions, not to engage in direct management.

In relation to business entities, direct management methods are not applicable at all. When working with enterprises and institutions that are not part of the public sector of the economy, indirect management methods are used: promoting the formation of specialized infrastructure, investing in services, promoting the development of forms of closer interaction between enterprises included in territorial clusters, lobbying for the interests of the territory at other levels of public power, etc. 
Along with the obvious advantages, strategic management has a number of drawbacks and limitations in its use, which indicate that this type of management, as well as all others, does not have the universality of application in any situation to solve any problems:

1. Strategic management, by its essence, does not provide an accurate and detailed picture of the future. The future desired state of the organization formed in strategic management is not a detailed description of its internal and external position, but rather, a qualitative wish for the state in which the organization should be in the future, what position to take in the market and in business, what organizational culture to have, be part of which business groups, and all this in aggregate should be that, which will determine whether or not the organization will survive in the future in competition. Strategic management cannot be reduced to a set of routine procedures and schemes, it does not have a descriptive theory that prescribes what and how to do when solving certain problems or in specific situations.

Thus, strategic management is rather a certain philosophy or ideology of business and management. And each individual manager understands and implements it to a large extent - in its own way, but there are a number of recommendations, rules and logical diagrams for analyzing problems and choosing a strategy, as well as implementing strategic planning and practical implementation of the strategy.

2. Strategic management is a symbiosis of the intuition and art of senior management to lead the organization to strategic goals, high professionalism and creativity of employees, ensuring the organization's connection with the environment, updating the organization and its products, as well as implementing current plans and, finally, actively including all employees in the implementation of the organization's goals, in the search for the best ways to achieve its goals.

3. Enormous effort and time and resources are required for the organization to begin its strategic management process. It is necessary to create and implement strategic planning, which is fundamentally different from the development of long-term plans that are mandatory under any conditions. The strategic plan must be flexible, responsive to changes within and outside the organization, and requires very much effort and cost. You also need to create services that monitor your environment and include your organization in your environment. The services of marketing, public relations, etc. acquire exceptional importance and require significant additional costs.

4. The negative consequences of strategic foresight errors are sharply increasing. In conditions where completely new products are created in a short time, when investment directions change dramatically in a short time, when new business opportunities suddenly arise and many years of opportunities disappear before our eyes, the price of reckoning for incorrect foresight and, accordingly, for errors of strategic choice, it often becomes fatal for the organization. Especially tragic are the consequences of an incorrect forecast for organizations implementing a non-alternative way of functioning or implementing a strategy that is not subject to fundamental adjustment.

5. Strategic management often focuses on strategic planning. In fact, the implementation of the strategic plan is an essential component of strategic management. And this involves first of all creating an organizational culture that allows you to implement a strategy, create motivation and organization of labor, create a certain flexibility in the organization, etc. At the same time, in strategic management, the implementation process has an active opposite effect on planning, which further enhances the significance of the implementation phase. Therefore, an organization (a State or a State body) will not be able, in principle, to move to strategic management if it has created, even if it is very good, a subsystem of strategic planning and there are no prerequisites or opportunities for creating a subsystem of strategic implementation (Vikhansky, 2006).

\section{Results}

Thus, speaking about the management of the territorial economy of the region, we consider two main types of management: current and strategic. Despite the serious differences between these types of management, they have a common subject of management - a public authority. Attempts to allocate individual state or municipal organizations for strategic management (in the USA in the 70s of the XX century, in the UK in the 80 s of the XX century) have shown that this is possible only for the implementation of individual programs and projects (Gordon, 2005).

Therefore, the main form of territorial management is the combination of current and strategic management within the governing body. The implementation of this approach requires a very careful attitude to the construction of the internal structure of the management body, taking into account the peculiarities of the organization of different types of management. Let's try to give a more detailed description of the main approaches to building management structures focused on combining current and strategic management. 
Currently, in theory and in practice, a fairly homogeneous view has been formed regarding the structure of strategic management, the main components of which are: Strategic planning (a special type of management activity, consisting in the development of strategic solutions that include such goals and strategies for the behavior of management objects, the implementation of which ensures their effective functioning in the long term, rapid adaptation to changing conditions of the external environment, implementation of the strategy and strategic control (Strategic planning in Russian municipalities, 2010).

Strategic planning first began to be applied in Europe and the USA in the 1970s. Strategic planning at the level of a municipality can be defined as "a systematic process through which local communities (with the participation of all stakeholders) create a picture of their future, based on local resources, external and internal conditions, and determine stages and activities to achieve the intended goals (Hrabrov, 2013).

The strategic development plan can be seen as a document reflecting the desired future state of the economic and social structure of the region (goal) and a way to use available and feasible resources to achieve this.

The basic principles of strategic planning for the development of territories are:

1. Reliance on available resources. Objective accounting of material, financial, labor and scientific resources will make it possible to correctly assess the competitive advantages and opportunities of the territory and determine the main directions of its development.

2. Taking into account historical and spatial-geographical features and patterns of development of the territory. It is impossible to disrupt the natural economic and socio-cultural course of events, and it is necessary to continue them creatively.

3. Taking into account world development trends, as well as scientific, technical and socio-economic processes.

4. Finding allies. Alone, regional territories, and especially individual municipalities, cannot cope not only with the implementation of the plan, but also with current problems. Allies should be sought in all instances and areas: among higher authorities, in the entrepreneurial environment, the media, and science. We cannot do without a positive public opinion.

5. Excluding imitation. Do not seek to become a shadow of another territory (Pizarenko, Dolgach, 2008).

In order to understand the problems hindering the spread of strategic planning, it should be borne in mind that, firstly, it is not adequate for the establishment by society of a certain order and the unquestionable implementation of activities strictly in accordance with previously developed tasks, that is, it is not built on the basis of command orders. Secondly, in strategic planning, the achievement of the future is not realized as a rigid line of behavior, but acts as a motion vector that can constantly adjust its orientation under the influence of newly emerging conditions and factors. The main thing here is the implementation of the mission of development of the territory. Thirdly, strategic planning is not a self-regulatory system that is influenced by and adapts to external conditions.

\section{Discussions}

N.V. Chepurnyh, A.V. Merzlov, A.L. Novoselov, note: "It should be noted that the strategic plan is not a law or decree mandatory for the administration, entrepreneurs and citizens. It is mandatory as much as the administration considers it the basis of its economic policy. "(Chepurnyh et al, 2006).

The origins of strategic planning for economic development are in the analysis of organizational behaviour. Only after understanding the possibilities of this type of planning at the organizational level can we talk about transferring its principles to territorial planning. In this regard, one of the ways to theoretically ensure territorial development is to borrow developments accumulated in the framework of strategic planning in enterprises (Efremov, 1999).

Currently, some regions and territorial entities do not have strategic development plans, and in some cases, existing plans are considered only as a description of the general vector of development of the Territory, regardless of the need to carry out any measures to implement these plans.

- it is clearly understood that it is impossible to predict the state of the territorial environment in the future;

- There is an inextricable link between the Territory and its political environment, and it is not possible to pursue an independent line of development without coming into conflict with that environment.

An alternative option for territorial behaviour is active interaction with the external environment through strategic planning activities. 
The impact of strategic planning activities at the territorial level can be presented in the following diagram (Figure 1).

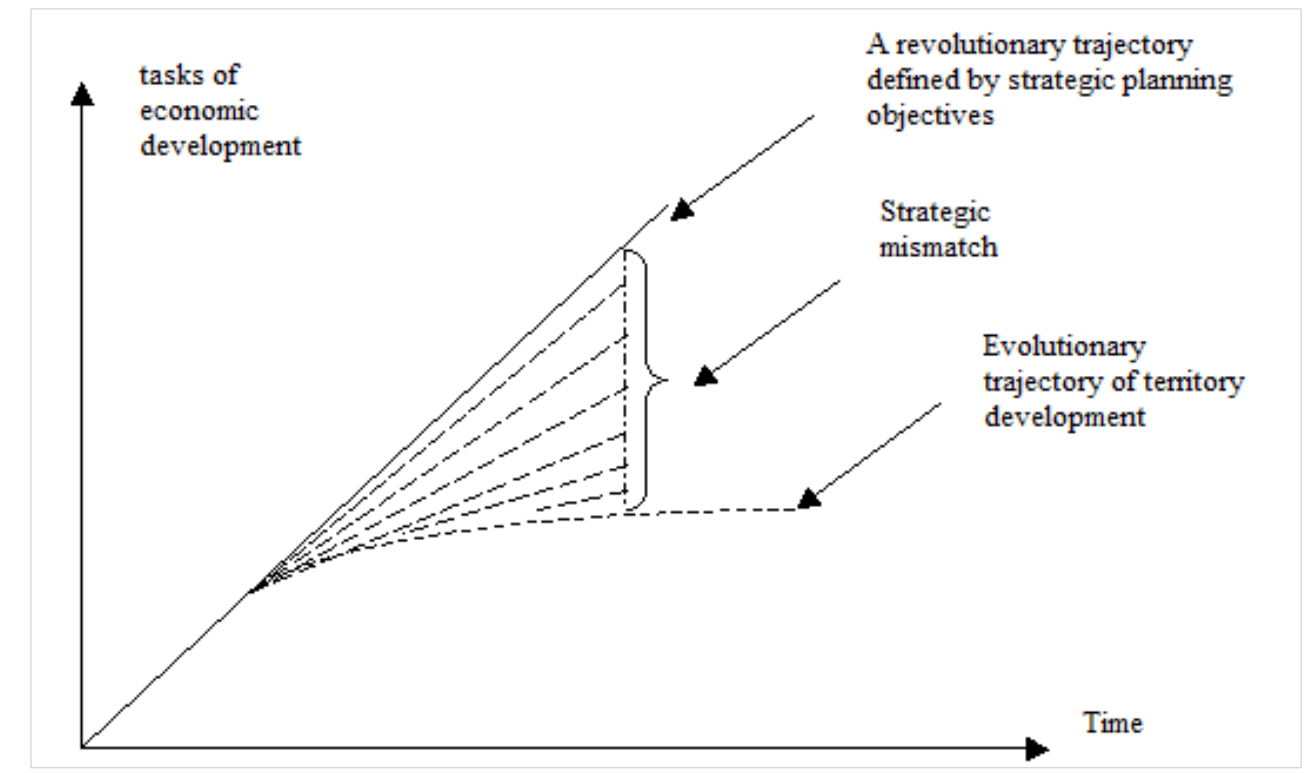

Figure 1. Territory development using strategic planning tools

Note - compiled by the authors

Consider the essence of strategic planning by analyzing the various definitions of this concept. At the same time, we note that most definitions are related to planning at the organizational level. G. Mintzberg highlights the following planning understandings: (Mintzberg, 2000).

1. Planning as thinking about the future;

2. Planning as control of the future;

3. Planning as decision-making;

4. Planning as an integrated decision-making process;

5. Planning as a formalized result formulation procedure in the form of an integrated solution system.

However, in this case, both understandings of the strategy are correct, since the strategy involves the presence of a certain list of actions (plan) and serves as a model for the actions being implemented.

V.S. Bochko writes: "We need creative coordinated actions of the authorities, all structures and social groups. Such an opportunity is presented by the development and implementation of strategic development plans of the Territories, that is, integrated developing and solving social issues not only on the basis of the residual principle, but on the basis of targeted programmatic development. " (Bochko, 2010). According to V.S. Bochko, the positive sides of the strategic plans are:

- Systematic resolution of objective contradictions;

- The integrated use of resources in the Territory;

- Targeted structural adjustment in the Territory towards diversification of the economy and services;

- Moving away from the "raw material" focus of the development of the local economy;

- Subordination of investment activities to create comfortable industrial and cultural conditions for the population of the territories;

- Gradual approximation of municipal economies to world-class development standards.

\section{Conclusions}

When forming a strategic planning mechanism, one should proceed from the need to respect the interests of all participants in the development of the territory: government, business, and the public. But the driving force is always the government: it not only realizes its interest, but also creates conditions for the effective functioning of enterprises, improving the investment climate of the territory, provides equal competitive opportunities for all partners in the region. A well-developed strategic plan is the basis for implementing more detailed plans for each year. At the same time, it should be borne in mind that the strategic plan does not represent a guarantee of the implementation of the envisaged development strategies, but is only an im- 
portant tool that helps to implement the chosen directions of development. It is always based on information that was known during its development. The main results of the strategic plans will be:

- Improving the Territory's competitiveness;

- Developing a new way of thinking about the forms and methods of development of the Territory;

- Formation on the territory of structures - locomotives of economic development;

- Synthesis of state municipal regulation and market self-regulation;

- Formation of a new corporate type of relationship between government, business, the public and other entities.

The end result of the strategic development of the territory is the achievement of the social effect of the activities carried out, which consists in improving the well-being of the population living in this territory of the region.

\section{References}

Bochko, V.S. (2010). Teoretiko-metodologicheskie osnovy integrativnogo strategicheskogo razvitiya territorij [Theoretical and methodological foundations of the integrative strategic development of territories]. Extended abstract of Doctor's thesis. Yekaterinburg.

Efremov, V.S. (1999) Strategicheskoe upravlenie v kontekste organizacionnogo razvitiya [Strategic management in the context of organizational development]. Management in Russia and abroad, 1, 3-13.

Gordon, Gerald L. (2005) Strategic Planning for Local Government. Intl City County Management Assn

Gruzdev, A. (2008) Strategiya razvitiya regiona: celi, preimushchestva, tekhnologiya razrabotki [Regional development strategy: goals, advantages, development technology]. Obshchestvo i ekonomika [Society and economics], 1, 115-120.

Merenkova, I.N. (2011) Ustojchivoe razvitie sel'skih territorij: teoriya, metodologiya, praktika [Sustainable development of rural areas: theory, methodology, practice]. Voronezh: GNU NIIEAPK CCR of Russia.

Mintzberg, H. (2000) The rise and fall of strategic planning. Pearson Education.

Pizarenko, N. L. \& Dolgach, A.A. (2008) Strategic Management. Moscow: INFRA-M, Higher Education.

Hrabrov, E.A. (2013) Sovershenstvovanie informacionno-analiticheskogo obespecheniya strategicheskogo planirova-niya social'no-ekonomicheskogo razvitiya municipal'nyh obrazovanij [Improvement of information and analytical support for strategic planning of socio-economic development of municipalities]. Extended abstract of candidate's thesis. Maykop.

Strategicheskoe planirovanie $v$ rossijskih municipalitetah [Strategic planning in Russian municipalities]. (2010). Moscow: Municipal Power, 5.

Vikhansky, O.S.(2006) Strategicheskoe upravlenie [Strategic management]. Moscow: Economist.

Chepurnyh, N.V., Novoselov, A.L., Merzlov, A.V. (2006) Regional'noe razvitie. Sel'skaya mest-nost' [Regional development. Countryside]. Moscow: Nauka

Bezler, O. \& Borbasova, Z. (2018) Econometric assessment of factors of graduate employability. Journal of Applied Economic Sciences, 13, 1733-1738.

Borbasova, Z., Ossik, Y., Tolysbayev, B., Ulakov, S. \& Marat, S. (2017) Some elements of the expansion mechanism in the world economy. Journal of Advanced Research in Law and Economics, 8, 1094-1099.

Mamrayeva, D.G. (2017). Features of the development of innovative systems in the foreign countries. Bulletin of the Karaganda University. «Economy» series, 3, 99-108.

Tleuberdinova, A.T., Salauatova, D.M. \& Akhmetova, S.E. (2016) Iz zarubezhnogo opyta stranovogo brendinga [According to foreign experience of country branding]. Bulletin of the Karaganda University. «Economy» series, 1, 99-105 [in Russian].

Khussainova, Zh.S., Zhartay, Zh., Semak, E.A. \& Gordeyeva, Ye.A. (2018) The features of «productive» function of the state as economic subject. Bulletin of the Karaganda University. "Economy» series, 1 , 183-190.

\section{3.Н. Борбасова, Р.Е. Несипбаев, С.Н. Улаков, Н.С. Улаков}

\section{Аумақтарды ағымдағы және стратегиялық басқару тетіктерін пайдалана отырып, өңірлерді дамытуды жетілдіру}

\section{Андатпа}

Maқcambl: Өңірлерді табысты дамыту үшін сенімділік және болашаққа қатысты шоғырландырушы идеялардың болуы қажет. Бұл бизнестің және қоғамның маңызды қажеттіліктері, олар аумақтық әлеуметтікэкономикалық жоспарлау, ең алдымен стратегиялық жоспарлау механизмі арқылы қанағаттандырылады. 
Әдісі: Зерттеу барысында келесідей әдістер қолданылған: бақылау, жалпылау, салыстыру, талдау, жүйелік тәсілдеме, ақпараттарды жүйелеу, өңдеу.

Kорытынды: Стратегиялық жоспарлау тетігін қалыптастыру кезінде аумақты дамытудың барлық қатысушыларының: биліктің, бизнестің, қоғамның мүдделерін сақтау қажеттілігін ескеру қажет. Бірақ билік әрқашан қозғаушы күш болып табылады: ол өзінің қызығушылығын жүзеге асырып қана қоймай, кәсіпорындардың тиімді жұмыс істеуіне, аумақтың инвестициялық климатын жақсартуға жағдай жасайды және аймақтағы барлық серіктестер үшін тең бәсекелестік мүмкіндіктерді қамтамасыз етеді. Жақсы дамыған Стратегиялық жоспар жыл сайын егжей-тегжейлі жоспарларды жүзеге асырудың негізі болып табылады. Бұл ретте стратегиялық жоспар көзделген даму стратегияларының орындалуына қандай да бір кепілдік болып табылмайтынын, тек таңдап алынған даму бағыттарын іске асыруға көмектесетін маңызды құрал болып табылатынын есте ұстаған жөн. Ол әрқашан оны жасау кезінде белгілі болған ақпаратқа негізделген.

Тұжырымдама: Осылайша, аймақтың аумақтық экономикасын басқару туралы айта отырып, біз басқарудың екі негізгі түрін қарастырамыз: қазіргі және стратегиялық. Басқарудың осы түрлерінің арасындағы айтарлықтай айырмашылықтарға қарамастан, оларда жалпы басқару субъектісі - мемлекеттік орган бар. Демек, аумақтық экономиканы басқарудың негізгі нысаны басқару органы шеңберіндегі ағымдағы және стратегиялық басқарудың үйлесімі болып табылады. Бұл тәсілді жүзеге асыру басқару органының ішкі құрылымын құруға, басқарудың әртүрлі түрлерін ұйымдастырудың ерекшеліктерін ескеруге өте мұқият қарауды қажет етеді. Ағымдағы және стратегиялық басқаруды біріктіруге бағытталған басқару құрылымдарын құрудың негізгі тәсілдеріне егжей-тегжейлі сипаттама беруге тырыстық.

Кілm сөздер: өңір, аумақтықтың экономикасы, стратегия, механизм, ақпарат, аумақтық әлеуметтікэкономикалық жоспарлау.

\section{3.Н. Борбасова, Р.Е. Несипбаев, С.Н. Улаков, Н.С. Улаков}

\section{Совершенствование развития регионов с использованием механизмов текущего и стратегического управления территорией}

\section{Аннотация}

Цель: Для успешного развития регионов нужны определенность и наличие консолидирующих идей по поводу будущего. Это важные потребности бизнеса и общества, которые удовлетворяются через механизм территориального социально-экономического планирования, прежде всего, стратегического планирования. В статье рассмотрено понятие стратегического управления, описаны отличия стратегического и текущего управления на примере управления отраслями социального блока. Также исследована сущность управления территориальным хозяйством региона, а также вопросы реализации жизнеобеспечения и социального обслуживания населения, совершенствования территориального хозяйства в целом, приобретение им новых качественных характеристик более высокого уровня.

Memoдbl: При проведении исследования были использованы следующие методы: эмпирический, аналитический, синтетический и сравнительно-логический.

Pезультаты: Следовательно, основной формой управления территориальным хозяйством является сочетание текущего и стратегического управления в рамках органа управления. Реализация такого подхода требует очень внимательного отношения к построению внутренней структуры органа управления, учета особенностей организации разных видов управления. Попытаемся дать более развернутую характеристику основных подходов к построению структур управления, ориентированных на совмещение текущего и стратегического управления.

Bblвoдbl: При формировании механизма стратегического планирования следует исходить из необходимости соблюдения интересов всех участников развития территории: власти, бизнеса и общественности. Но движущей силой всегда выступает власть: она не только реализует свой интерес, но и создает условия для эффективного функционирования предприятий, улучшения инвестиционного климата территории, обеспечивает равные конкурентные возможности для всех партнеров в регионе. Грамотно разработанный стратегический план является основой для осуществления более подробных планов на каждый год.

Ключевые слова: регион, экономика территории, стратегия, механизм, информация, территориальное социально-экономическое планирование.

\section{References}

Бочко В.С. Теоретико-методологические основы интегративного стратегического развития территорий [Текст]: автореф. дис. ... д-ра экон. наук: 08.00.01 / В.С. Бочко. - Екатеринбург, 2010. — 40 с.; ил. — Библиогр.: C. $39,40$.

Ефремов В.С. Стратегическое управление в контексте организационного развития / В.С. Ефремов // Менеджмент в России и за рубежом. - 1999. - № 1. - С. 3-13.

Gordon G.L. Strategic Planning for Local Government. — Washington DC, 1993. — 168 p.

Груздев А. Стратегия развития региона: цели, преимущества, технология разработки /А. Груздев // Общество и экономика. - 2008. - № 1. - С. 115-120. 
Меренкова И.Н. Устойчивое развитие сельских территорий: теория, методология, практика / И.Н Меренкова. — Воронеж: ГНУ НИИЭОАПК ЦЧР России, 2011. — 265 с.

Mintzberg, H. The rise and fall of strategic planning / H. Mintzberg. — Pearson Education, 2000. - 458 p.

Писаренко Н.Л. Стратегическое управление / Н.Л. Писаренко, А.А. Длигач. — М.: ИНФРА-М; Высшее образование, 2008. - С. 37-41.

Храбров Е.А. Совершенствование информационно-аналитического обеспечения стратегического планирования социально-экономического развития муниципальных образований: дис. ... канд. экон. наук: 08.00.05 / Евгений Александрович Храбров [Место защиты: Адыг. гос. ун-т]. — Майкоп, 2013. — 221 с.; ил. РГБ ОД, $6114-8 / 657$

Стратегическое планирование в российских муниципалитетах. - М.: РИЦ «Муниципальная власть», 2010 Вып. 5. Муниципальное управление - $163 \mathrm{c.}$

Виханский О.С. Стратегическое управление / О.С. Виханский. — М.: Экономистъ, 2006. - 293 с.

Чепурных Н.В. Региональное развитие. Сельская местность / Н.В. Чепурных, А.Л. Новоселов, А.В. Мерзлов. М.: Наука, 2006. - 384 c.

Bezler O., Borbasova Z. Econometric assessment of factors of graduate employability // Journal of Applied Economic Sciences - 2018. - № 13. - C. 1733-1738.

Borbasova, Z., Ossik, Y., Tolysbayev, B., Ulakov, S. \& Marat, S. (2017) Some elements of the expansion mechanism in the world economy // Journal of Advanced Research in Law and Economics - 2017. — № 8. - C. 1094-1099.

Мамраева Д.Г. Особенности развития инновационных систем зарубежных стран / Д.Г. Мамраева // Вестн. Караганд. ун-та. Сер. Экономика. — 2017. - № 3(87). — С. 99-108.

Тлеубердинова А.Т. Из зарубежного опыта странового брендинга / А.Т. Тлеубердинова // Вестн. Караганд. унта. Сер. Экономика. — 2016. - № 1(81). - С. 99-105.

Хусаинова Ж.С. Особенности «производственной» функции государства как экономического субъекта / Ж.С. Хусаинова, Ж.М. Жартай, Е.А. Семак, Е.А. Гордеева // Вестн. Караганд. ун-та. Сер. Экономика. 2018. — № 1(89). - C. 183-190. 